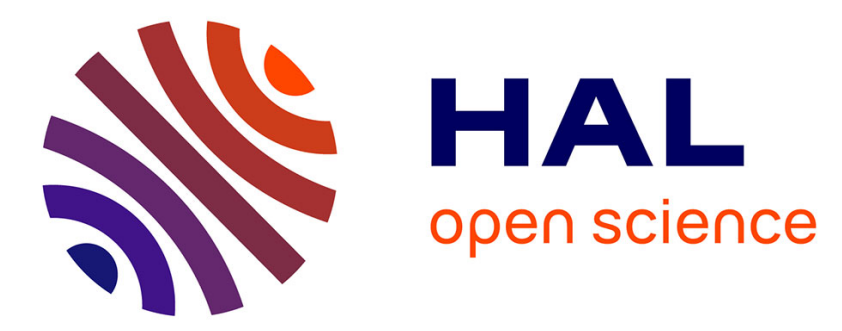

\title{
Radial distribution of carbohydrate reserves in the trunk of declining European beech trees (Fagus sylvatica L.)
}

Bastien Gérard, Nathalie Bréda

\section{To cite this version:}

Bastien Gérard, Nathalie Bréda. Radial distribution of carbohydrate reserves in the trunk of declining European beech trees (Fagus sylvatica L.). Annals of Forest Science, 2014, 71 (6), pp.675-682. 10.1007/s13595-012-0240-1 . hal-01102697

\section{HAL Id: hal-01102697 https://hal.science/hal-01102697}

Submitted on 13 Jan 2015

HAL is a multi-disciplinary open access archive for the deposit and dissemination of scientific research documents, whether they are published or not. The documents may come from teaching and research institutions in France or abroad, or from public or private research centers.
L'archive ouverte pluridisciplinaire HAL, est destinée au dépôt et à la diffusion de documents scientifiques de niveau recherche, publiés ou non, émanant des établissements d'enseignement et de recherche français ou étrangers, des laboratoires publics ou privés.

$$
\text { Copyright }
$$




\title{
Radial distribution of carbohydrate reserves in the trunk of declining European beech trees (Fagus sylvatica L.)
}

\author{
Bastien Gérard • Nathalie Bréda
}

Received: 17 May 2012 / Accepted: 21 August 2012 / Published online: 14 September 2012

(C) INRA / Springer-Verlag France 2012

\begin{abstract}
- Context European beech (Fagus sylvatica L.) is considered threatened by anticipated climate change, but the physiological causes of potential beech decline or mortality remains poorly understood.

- Aims The purpose of the present study was to fuel debate about the assumption that carbohydrate depletion is involved in the decline of mature European beech.

- Methods The health status of beech trees from a severely declining stand was visually assessed by examining their crown condition. Content and radial distribution of nonstructural carbohydrates (starch and soluble carbohydrate) were analyzed in the trunks and compared to those reported earlier in trunks of healthy beech trees.

- Results and discussion The distribution of carbohydrate in the beech trunks recorded here seemed affected by decline. We found a stronger radial decrease of starch content than those reported earlier for healthy beech trees. Carbohydrate reserves appear partially maintained in the outermost rings while starch depletion occurred in older wood rings in
\end{abstract}

\footnotetext{
Handling Editor: Erwin Dreyer

Contribution of the co-authors Bastien Gérard realized all the carbohydrate measurements and related data analysis and results presentations and took the initiative of the literature review. Both authors have written the manuscript together. Nathalie Bréda was the scientific leader of the two related research programs who funded this work (ANR-06-VULN-004 and DGAAL project 2009-215).
}

B. Gérard $\cdot$ N. Bréda $(\bowtie)$

INRA, UMR 1137 Ecologie et Ecophysiologie Forestières,

54280 Champenoux, France

e-mail: breda@nancy.inra.fr

B. Gérard

e-mail: bastien.gerard@nancy.inra.fr

B. Gérard • N. Bréda

Université de Lorraine, UMR1137 Ecologie et Ecophysiologie

Forestières,

54280 Champenoux, France declining trees that may be able to mobilize carbohydrate reserves from older wood rings in response to successive climatic constraints.

Keywords Crown condition · Decline $\cdot$ Non-structural carbohydrates $\cdot$ Starch $\cdot$ Storage $\cdot$ Water balance

\section{Introduction}

Tree mortality is a natural process that is predicted to increase as a result of increasing frequencies of climatic hazards combined with increased pest and disease pressures (DesprezLoustau et al. 2006; Rouault et al. 2006; McDowell et al. 2011). Decline is characterized by symptoms that cannot be explained by simple interpretations, as it results from multiple abiotic and biotic stressors (Manion 1991). Tree decline is defined by a long-lasting worsening of visible features that would predict tree mortality. Decline symptoms include reduced primary and secondary growth in trunks, branches and twigs, crown-thinning, and transparency (due to leaf loss, twigs abscission, and reduction in leaf area), resulting in a clumping of the foliage related to shortened internodes (Manion 1991; Innes 1998). Therefore, these symptoms are commonly used to assess tree vitality, from healthy to dead trees (Innes 1998; Dobbertin 2005). Using growth reduction and crown condition, decline has been detected in many beech stands in Europe following each severe drought episode by the forest health monitoring program ICP Forests (see website, reports, and references therein). Many recent studies have related the sensitivity of beech (Fagus sylvatica L.) to water balance and warming temperatures in terms of radial growth (van der Werf et al. 2007; Michelot et al. 2012) or regeneration (E Silva et al. 2012), which greatly affects the actual distribution of beech (Badeau et al. 2010). Ecophysiological analyses have confirmed its sensitivity to soil water shortages (Leuschner et al. 2001; Granier et al. 2008). 
Overall, beech is likely to be highly vulnerable to a warmer, drier climate (Geßler et al. 2007), and foresters fear that cases of beech decline are likely to increase in coming decades. This is a matter of concern because Fagus is one of the most widespread temperate broadleaved species in Europe.

Beech growth is particularly sensitive to the climatic conditions of the current growing season (Michelot et al. 2012), but Granier et al. (2008) also observed that decrease in radial growth and foliar losses persisted for one year after summer water shortage and may recover thereafter. In some cases, according to Dobbertin (2005) and Bréda et al. (2006), extreme early drought event (as in 2003) may affect tree growth almost immediately, while leaf loss may occur later or not at all. Thus, short-term responses may not coincide with long-term changes of tree health. Unexpectedly and despite its sensitivity to drought, the mortality rate of beech trees remains relatively low (Eichhorn et al. 2005). Therefore, the physiological causes of beech decline that can lead to death are poorly understood. Climatic hazards can have long-term impacts on growth that could be linked to the availability of carbohydrate reserves (Bréda et al. 2006), and observed growth responses of beech trees to climatic variations indicate that changes in the allocation of carbon in trees may be important indicators of tree health status (Eichhorn et al. 2005; Bréda et al. 2006). Survival and long-term growth in trees or climate-driven tree mortality may be in part linked to the amount of available carbohydrates (McDowell et al. 2011).

Carbohydrate reserves are especially mobilized during periods without net carbon gain through photosynthesis and when demand for $\mathrm{C}$ arises. Carbohydrates are used: for maintenance, growth resumption, and foliage building during the spring; for protecting trees' physiological integrity (e.g., osmotic pressure, energy status...) against environmental stresses such as drought, waterlogging, frost, and also as defenses against pests and pathogens (Körner 2003). F. sylvatica is a diffuse-porous tree species that lacks clear sapwood because no true heartwood is formed, i.e., with enhanced phenolics (Magel et al. 1997). In contrast with heartwood or discolored wood, non-discolored trunks of healthy beeches contain high amounts of storage carbohydrates even in the oldest wood rings close to the pith (Magel et al. 1997; Hoch et al. 2003). Nevertheless, the composition of the inner-wood rings in the trunk of adult trees has been rarely analyzed. In the trunk of healthy beech, seasonal variations of carbohydrate reserves are almost entirely restricted to the most recent wood rings (Barbaroux and Bréda 2002; Hoch et al. 2003). However, we do not yet know the extent to which dynamics and radial distribution of carbohydrate reserves are affected in declining beech trees.

In the presented study, we investigated the carbohydrate content in trunks of mature beech trees in a severely declining stand as evidenced by visual assessment of crown condition. We addressed the following question: are there changes in the radial distribution of carbohydrate reserves in the trunk associated with decline in this heartwood-lacking species?

\section{Material and methods}

2.1 Study site, stand water balance, and stand characteristics

The study was conducted in the "Bas Bois" state forest (329.7 ha), composed of common beech and oaks (respectively, $65 \%$ and $14 \%$ of area) and managed as high forest in north-eastern France (10 km south of Sarrebourg). Beech trees were sampled in a mature stand (100 to 130 years old, stand $\mathrm{n}^{\circ} 16 \mathrm{a}$ ), located $48^{\circ} 37^{\prime} 44^{\prime \prime} \mathrm{N}$ and $7^{\circ} 03^{\prime} 13^{\prime \prime E}, 350 \mathrm{~m}$ a.s.l. The mean annual temperature is $9.2{ }^{\circ} \mathrm{C}$, and the mean annual precipitation is $820 \mathrm{~mm}$ (Hesse INRA weather station, $8 \mathrm{~km}$ away). At the time of the study, the mean stem diameter at breast height of the beech trees was $55 \mathrm{~cm}$, dominant height was $32 \mathrm{~m}$.

The soil type is intermediate between luvisol and stagnic luvisol, with $150 \mathrm{~mm}$ extractable water. In order to quantify drought and water excess events that occurred during the recent years, daily soil water balance was computed using soil properties, stand inventories to derive stand leaf area index and daily climatic data from 1999 to 2009 with the Biljou $\odot$ model (Granier et al. 1999). The model calculates daily each elementary vertical water flux (tree transpiration, understorey evapotranspiration, rainfall interception, water excess) and as a result soil water content. Stand transpiration is calculated under the big-leaf assumption using potential evapotranspiration and stand LAI. Relative soil extractable water (REW, dimensionless) was computed to quantify drought events, i.e., when REW drops below a 0.4 threshold. Under this threshold, trees are submitted to water shortage leading to stomatal closure and growth slowdown. On the opposite, when soil water content reaches field capacity, the water balance calculates an excess of water (EW, in millimeter).

The "Bas Bois" state forest was strongly affected by storm Lothar on December 26, 1999. According to the forest management plan, the monitoring plot was set up in an area where wind-throw accounted for $25 \%$ of the pre-storm standing volume. Damaged trees were extracted quickly and carelessly with heavy machinery which led to soil compaction and areas prone to waterlogging. As a result of soil damage, subsequent years showed development and expansion of localized areas of sedges and rushes.

During 2005, foresters were concerned by beech decline, with crown deterioration and various timber defects in all surrounding beech stands in this forest. A survey plot was established in July 2006 by the French Forest Health Department (DSF, Département de la Santé des Forêts) and the 
National Forest Office (ONF, Office National des Forêts) to monitor changes in tree condition. Two sets of beeches growing together were selected according to their stage of decline: trees in poor health (set A), and trees more severely affected by dieback (set B), consisting of 8 and 10 trees, respectively. The A set consisted of trees with leaf losses below $55 \%$. Those of the B set had leaf losses above $60 \%$ and hence were in poor health condition. They were identified and numbered in 2006, and their health status was visually assessed annually until 2009 , according to the ICP manual for harmonized assessment and monitoring of crown condition used in the European survey network. Crown transparency was assessed from the ground using binoculars, and leaf losses and dead branches were recorded as percentages of the total potential complement of the upper tree-crown, in classes of $5 \%$ and $10 \%$, respectively. During autumn 2009 , the stand was totally harvested.

\subsection{Wood sampling}

Wood sampling was performed on October 13, 2008 from each selected tree at $0.3 \mathrm{~m}$ height. This coring height was chosen to avoid commercial depreciation of the timber and because sampling near the stump has been shown to be suitable for carbohydrate status diagnosis (Barbaroux and Bréda 2002). The sampling date was chosen when the carbohydrate content of beech stems is maximal (end of the growing season) and before any starch interconversion due to chilling (Barbaroux and Bréda 2002; El Zein et al. 2011). The cores (5 mm diameter and $10 \mathrm{~cm}$ long) were taken with increment borer, transported with a freeze-pack from field to the laboratory and quickly stored at $-20{ }^{\circ} \mathrm{C}$ until freeze-drying (using a Dura-Top instrument, supplied by Dura-Dry FTS Systems, NY, USA).

Each sampled core was fractionated into 2-cm sections starting below the cambium (bark was removed), ground to a fine powder (using an MM301 Mixer Mill, Retsch, Germany) and then stored in the dark in airtight vials until analysis.

\subsection{Carbohydrate extraction and analysis}

Total non-structural carbohydrates (TNC) were extracted, according to methods adapted from Barbaroux and Bréda (2002) and Gérard et al. (2009), from the powdered samples containing $20 \mathrm{mg}$ of dry matter (DM) by incubating them for $20 \mathrm{~min}$ at $80{ }^{\circ} \mathrm{C}$ in $0.5 \mathrm{~mL}$ of ethanol $80 \%(v / v)$, centrifuging the resulting suspension $(10 \mathrm{~min}$ at $15,000 \times \mathrm{g})$ and then collecting the supernatant (containing soluble carbohydrates). Incubation and centrifugation steps were repeated three times on each sample, the three resulting supernatants were pooled. The complete lack of soluble sugars in the pellet was checked during the protocol development and then during each starch analysis. The pellets and pooled supernatants were dried, for $15 \mathrm{~min}$ and overnight, respectively, in a speed vacuum evaporator (Maxi-Dry Plus, Heto model DW1, Denmark) to eliminate ethanol.

The dried extracts of soluble carbohydrates were rehydrated in $1.5 \mathrm{~mL}$ of distilled water, polyvinyl-polypyrrolidone was added to $20 \%$ of the powdered dry mass sampled, and the resulting suspensions were subjected to sonication and agitation to ensure that the soluble carbohydrates were completely dissolved. After centrifugation ( $5 \mathrm{~min}$ at $3,000 \times \mathrm{g}$ ), $1 \mathrm{~mL}$ of the supernatant was filtered through a $0.2-\mu \mathrm{m}$ Acrodisc Supor filter (VWR, USA) and stored in vials at $-20{ }^{\circ} \mathrm{C}$ until analysis. Soluble carbohydrates were quantified with high-pressure liquid chromatography system (Gold Beckman Coulter, Software 32 karat) equipped with a HyperRez XP Carbohydrate $\mathrm{Pb}^{2+}$ separation column $(8 \mu \mathrm{m}, 300 \times 7.7 \mathrm{~mm})$ and HyperRez $\mathrm{Pb}^{2+}$ $5 \times 3 \mathrm{~mm}$ precolumn (both from Thermo Electron, France), according to El Zein et al. (2011). The soluble carbohydrate peaks were detected using a Sedex 45 ELSD light scattering monitor (Sedere, Vitry sur Seine, France) and identified according to the retention times of commercial sucrose, glucose, and fructose standards. No other soluble carbohydrate compounds were detected. Their concentrations were determined from their peak heights after standard calibrations.

Starch was extracted and analyzed as described by Gérard et al. (2009). Briefly, starch was extracted from the ethanolinsoluble fraction of the samples (dried pellets) in a $0.2-\mathrm{N}$ $\mathrm{KOH}$ solution containing $100 \mathrm{mM}$ ethanol. The extracted starch was then hydrolyzed with amyloglucosidase (from Aspergillus niger, Sigma, EC 3.2.1.3) and the obtained glucose was assayed colorimetrically with an enzymatic method using $A$. niger Type II glucose oxidase (Sigma, EC 1.1.3.4) and horseradish Type I peroxidase (Sigma, EC 1.11.1.7) in the presence of $o$-dianisidine dihydrochloride (Sigma, EC 243-737-5). After adding $6 \mathrm{~N}$ hydrochloric acid, absorbance was measured at $530 \mathrm{~nm}$, using glucose as a standard. The starch concentration was expressed as glucose equivalents on a dry matter basis.

The consistency of the methods used in the current study for the analyses of soluble carbohydrates and starch with those of Barbaroux and Bréda (2002), Genet et al. (2010) and El Zein et al. (2011) has been tested using standard samples.

\subsection{Statistics}

All statistical analyses were performed with $\mathrm{R}$ version 2.11.0 (R Development Core Team 2010). Datasets did not follow normal distribution (Shapiro and Wilk test), thus non-parametric Mann-Whitney-Wilcoxon or KruskalWallis tests were used to compare means between two or more than two groups, respectively. 


\section{Results}

\subsection{Stand water balance}

Water excess occurred after the storm of December 1999, especially in springs 2000 to 2002 (Fig. 1), inducing possible waterlogging due to windblown trees removing. Four successive years exhibited soil water deficit (i.e., REW <0.4): 2003 to 2006, the earliest, longer and more severe one clearly occurred in 2003. This succession of drought episodes during the growing season was preceded and followed by wet years. After the dry years, 2007 was wet with high water excess in soil during the growing season, which was exceptional in that pedo-climatic context. The two last years (2008-2009) exhibited a more favorable water balance, with neither excess nor shortage of water.

\subsection{Symptomatic condition of the beech crowns}

In 2006, leaf loss and dead branch percentages were significantly higher in set B than set A $(p<0.001$ and 0.007 , respectively). Thus, crowns of beech trees in set $B$ were more damaged, overall, than those of set A (Fig. 2). During the years 2006 and 2007, leaf loss and fraction dead branches were on average 1.6- and 2.8-fold higher, respectively, in set B than in set A. Crown condition of set B remained almost stable throughout the observation period; leaf loss was on average $70 \%$ to $80 \%$, fraction dead branches was $45 \%$ to $60 \%$ (with a large variability among trees), and there were no significant $(p<0.05)$ between-year change in these variables. In contrast, a clear worsening of the crown condition occurred in set A: both leaf loss and fraction dead branches increased significantly ( $p=0.021$ and 0.007 , respectively) from 2006 to 2009 ; leaf deficit became larger than $50 \%$ and fraction dead branches doubled compared to previous years (Fig. 2).
3.3 Radial distribution of carbohydrate reserves in the trunk

No significant difference $(p>0.05)$ was detected in the radial distribution of either starch or soluble carbohydrates between trees from sets A and B (Fig. 3), i.e., no effect of crown condition on TNC contents and distribution was detected. TNC content was highest in the most recent and outer rings, in the first $2 \mathrm{~cm}$ of wood below the cambium. Beyond that point, TNC content decreased sharply, by about $50 \%$, mainly due to a sharp drop in starch content. Over $85 \%$ of the starch was located in the outer $2 \mathrm{~cm}$, and this decrease was highly significant $\left(p<1.610^{-8}\right)$. In contrast, soluble carbohydrate content remained relatively high even in the oldest inner rings, up to $10 \mathrm{~cm}$ below the cambium (Fig. 3). However, the decrease of total soluble carbohydrates with distance below the cambium was significant $(p<0.001)$. This decrease was due to a significant drop, of about $40 \%$, in the sucrose content $(p<5.7$ $10^{-5}$ ). However, whatever the radial section of the trunk, sucrose represented about half TNC content and was the main carbohydrate. Beyond $2 \mathrm{~cm}$ from the cambium, the significant drop in starch content $(p<1.6$ $10^{-8}$ ) was accompanied by slight increases in glucose and fructose contents, whose proportions increased as the starch content fell. However, the contents of both fructose and glucose remained stable and did not vary between wood sections $(p>0.05)$.

The results obtained from comparable trunk sections of the Bas Bois trees (averaged concentrations for 0 $8 \mathrm{~cm}$ or $0-10 \mathrm{~cm}$ radial trunk sections, Table 1) showed that TNC content was relatively low, with a tenfold lower starch content than that of the healthy beeches analyzed by Hoch et al. (2003). The radial reduction in TNC from the outermost wood ring to the pith was less pronounced in healthy trees than in the current study (Table 1). Barbaroux et al. (2003) and Hoch et al.

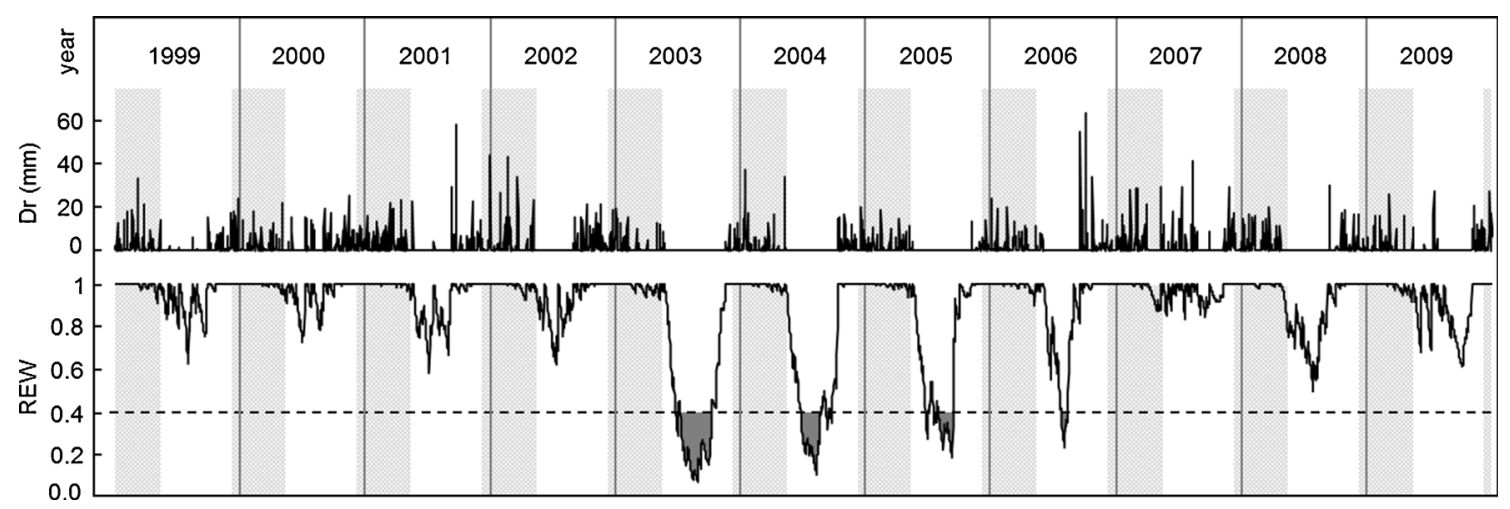

Fig. 1 Time course of modelled daily Relative Extractable soil Water (REW, dimensionless, 1 corresponds to field capacity, 0 to permanent wilting point) and water excess (WE, in millimeter) from 1999 to 2009.
The dashed line points out the threshold of REW $=0.4$, below which drought is defined (gray areas). Computed with Biljou $\mathcal{C}$, daily climatic data from Hesse weather station, INRA. Gray bands delineate the leafless periods 


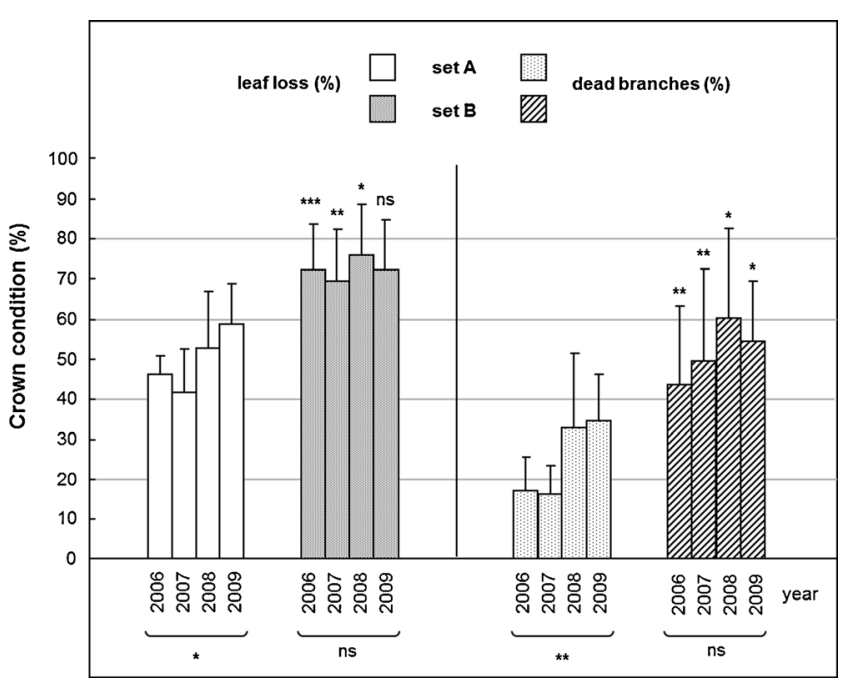

Fig. 2 Symptomatic crown parameters (leaf loss and numbers of dead branches, as percentages of the total potential complement of leaves and all branches, respectively; means and standard deviations) of beeches in the A and B sets in each year from 2006 to 2009. The symbols above the bars indicate significant differences between sets A and B at each date. The symbols under the dates indicate significant changes in the parameters for the set throughout the study period. Probability: $* * *<0.001<* *<0.01<*<0.05<$ not significant (ns)

(2003) found radial reductions in TNC contents of about $20 \%$ to $30 \%$ between 0 and $4 \mathrm{~cm}$ below the cambium, while we detected a stronger radial drop of about $55 \%$. This was especially due to the starch content that was

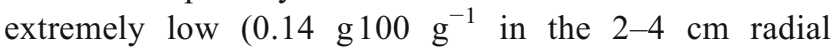
section). The $0-2 \mathrm{~cm}$ radial section contained almost $90 \%$ of the starch reserves of the trunks in the declining beeches from Bas Bois, compared to less than $50 \%$ in the healthy trees from earlier studies (Table 1).

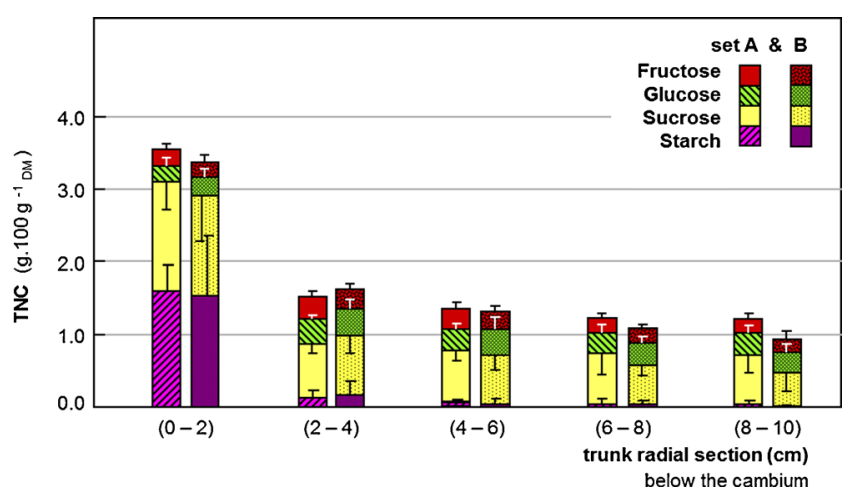

Fig. 3 Total non-structural carbohydrates (TNC), divided into starch and soluble carbohydrates (sucrose, glucose, and fructose), in grams per $100 \mathrm{~g}$ dry mass (DM), in 2-cm radial wood sections up to $10 \mathrm{~cm}$ deep below the cambium, in trunks of beeches of sets A and B, sampled at $0.3 \mathrm{~m}$ height in October 2008. Means with standard deviations

\section{Discussion}

4.1 Beech decline at Bas Bois related to multi-year adverse events

The heavy thinning of the stand due to the storm of December 1999 impacted the crown status of the standing trees, because of sudden increase in the crown spacing, often associated with increasing leaf loss (Eichhorn et al. 2005). Excess water occurred in the soil occurred as heavy rainfalls coincided with canopy opening (Fig. 1) due to reduced leaf area index, rainfall interception, and stand transpiration. Moreover, physical soil properties were worsened by soil compaction after tree harvesting while the soil was saturated (Schmuck, pers. comm.). Residual trees near skid trails may have suffered from soil compaction (Kozlowski 1999) leading to hypoxia that is highly damaging for beech (Dreyer 1994). After these successive wet years, the 2003 growing season was exceptionally hot and dry and mild droughts then followed, during which photosynthesis was restricted by stomatal closure. This reduced the net primary productivity and radial growth of beech trees (Geßler et al. 2007; Granier et al. 2008). Adding possible hydraulic failure in twigs during exceptional water shortage in 2003, both water and carbon relations were impaired, leading to worsening crown condition (Fig. 2, leaf losses, twig dieback), as reported by previous studies (Power 1994; Innes 1998). Crown thinning reduced in turn carbohydrate allocation to growth and storage (Bréda et al. 2006). None of these events was sufficiently harmful to cause sudden death; nevertheless, alternative periods of water shortage and excess, cumulated since 1999, have weakened the beech trees thereby leading to the stand decline, while TNC reserves were likely impaired.

\subsection{The beech trees appear to preserve their TNC reserves}

Although essential, TNC amounts required for spring growth recovery are relatively low in diffuse-porous species (Höll 1997; Palacio et al. 2011), including common beech (Barbaroux and Bréda 2002; Barbaroux et al. 2003; Genet et al. 2010; El Zein et al. 2011). Stem growth begins after leaf expansion and thus after the phase of $\mathrm{C}$ autotrophy has started early in spring. Moreover, radial growth may totally stop in some years in beech (resulting in missing rings) without endangering its survival. In many cases, cambial activity recovers completely in the following years if trees are not damaged by additional adverse events (Power 1994; van der Werf et al. 2007). Further, long-term monitoring of crown condition showed that beech trees exhibiting strong leaf losses after a drought event are able to recover in a few years (Dittmar and Elling 2007; Nageleisen, pers. comm.). In addition, $\mathrm{C}$ allocation to reserves is maintained, while allocation to growth decreases or completely ceases under soil water deficit (Barbaroux and Bréda 2002). Further, 
Table 1 Radial distribution of total non-structural carbohydrates (TNC), soluble carbohydrates (sC) and starch in beech trunks (expressed in gram per $100 \mathrm{~g}$ dry mass (DM)) at the end of growing season (late October), based on data from the studies in which radial analysis was performed

\begin{tabular}{|c|c|c|c|c|c|c|c|c|}
\hline \multirow[t]{2}{*}{ Reference } & \multirow[t]{2}{*}{ Forest stand location } & \multirow[t]{2}{*}{$\begin{array}{l}\text { Age }^{\mathrm{a}} \\
\text { (year) }\end{array}$} & \multirow[t]{2}{*}{$\begin{array}{l}\text { Diameter } \\
(\mathrm{cm})\end{array}$} & \multirow[t]{2}{*}{$\begin{array}{l}\text { Sampling } \\
\text { height }(\mathrm{m})\end{array}$} & \multirow[t]{2}{*}{$\begin{array}{l}\text { Trunk radial } \\
\text { section }\end{array}$} & \multicolumn{3}{|c|}{ 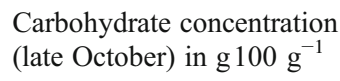 } \\
\hline & & & & & & $\mathrm{TNC}$ & $\mathrm{SC}$ & Starch \\
\hline \multirow{4}{*}{$\begin{array}{l}\text { Barbaroux and Bréda (2002), } \\
\text { Barbaroux et al. (2003) }\end{array}$} & \multirow[t]{4}{*}{ Hesse (Sarrebourg, France) } & \multirow[t]{4}{*}{35} & \multirow[t]{4}{*}{15} & \multirow[t]{4}{*}{1.3} & $0-2 \mathrm{~cm}^{\mathrm{b}}$ & 3.3 & 1.1 & 2.2 \\
\hline & & & & & $2-4 \mathrm{~cm}^{\mathrm{b}}$ & 2.3 & 1.0 & 1.3 \\
\hline & & & & & $4-8 \mathrm{~cm}^{\mathrm{c}}$ & 2.2 & 1.6 & 0.6 \\
\hline & & & & & $0-8 \mathrm{~cm}$ & 2.5 & 1.3 & 1.2 \\
\hline \multirow[t]{4}{*}{ Hoch et al. (2003) } & \multirow[t]{4}{*}{ Hofstetten (Basel, Switzerland) } & \multirow[t]{4}{*}{$70-100$} & \multirow[t]{4}{*}{32} & \multirow[t]{4}{*}{1.3} & $0-10 \mathrm{~cm}$ & 4.2 & 1.0 & 3.2 \\
\hline & & & & & $0-2 \mathrm{~cm}$ & 6.3 & - & - \\
\hline & & & & & $2-4 \mathrm{~cm}$ & 5.0 & - & - \\
\hline & & & & & $4-10 \mathrm{~cm}$ & 3.3 & - & - \\
\hline \multirow[t]{6}{*}{ Current study } & \multirow[t]{6}{*}{ Bas Bois (Sarrebourg, France) } & \multirow[t]{6}{*}{$\sim 110$} & \multirow[t]{6}{*}{55} & \multirow[t]{6}{*}{0.3} & $0-2 \mathrm{~cm}$ & 3.48 & 1.90 & 1.57 \\
\hline & & & & & $2-4 \mathrm{~cm}$ & 1.59 & 1.43 & 0.14 \\
\hline & & & & & $4-8 \mathrm{~cm}$ & 1.25 & 1.20 & 0.04 \\
\hline & & & & & $4-10 \mathrm{~cm}$ & 1.19 & 1.15 & 0.03 \\
\hline & & & & & $0-8 \mathrm{~cm}$ & 1.88 & 1.43 & 0.45 \\
\hline & & & & & $0-10 \mathrm{~cm}$ & 1.73 & 1.36 & 0.36 \\
\hline
\end{tabular}

The radial wood sections analyzed are specified as centimeter below the cambium, from the most recent to the oldest rings. To facilitate comparisons between studies, wherever possible, carbohydrate concentrations were calculated for wood sections of similar length

${ }^{\mathrm{a}}$ Trees exhibited contrasted ages, but ca. 20 years TNC contents of beech wood appear to be relatively stable during further ageing (Genet et al. 2010)

${ }^{\mathrm{b}}$ In this study, the ten most recent rings were analyzed spanning about $4.2 \mathrm{~cm}$; values for the $0-2$ and $2-4 \mathrm{~cm}$ sections are averages for the five most recent and five following rings, respectively

${ }^{\mathbf{c}}$ Estimated by subtracting the $0-4 \mathrm{~cm}$ section values from the $0-8 \mathrm{~cm}$ section values

- Missing information

carbon costs for reproductive functions increase with ageing, while stem growth declines, thereby maintaining a steady carbohydrate state (Genet et al. 2010). This view of carbohydrate management may partly explain the lack of relationships between crown conditions and carbohydrate reserves and is consistent with the idea of carbohydrates as active carbon reserves (Sala et al. 2012). Moreover, according to the ICP manual, the lower tree-crown is not taken into account for crown condition assessment, whereas it contributes positively to $\mathrm{C}$ assimilation. Therefore, as all the studied trees were declining, the range of health status might be insufficiently contrasted to result in significant changes of carbohydrate reserves. To some extent, the growth flexibility of beech trees may ensure carbohydrate reserve saving under adverse conditions, which could prevent carbohydrate depletion. Without additional adverse events, this strategy may enable high resilience when growing conditions improve. Nevertheless, over the accumulation of constraints that affect the growth, $\mathrm{C}$ assimilation and $\mathrm{C}$ allocation, during several consecutive years as in the current study could cause a prolonged $\mathrm{C}$ imbalance. The demands for carbohydrates to maintain metabolism may then require an extra-mobilization of reserves.
4.3 The radial distribution of TNC reserves in the trunk of beeches is likely affected by decline

Considering only the most recent, outer rings (in the $0-2 \mathrm{~cm}$ section below the cambium), TNC contents measured in the declining beech trees appear to be similar to those in many healthy ones (Barbaroux and Bréda 2002; Barbaroux et al. 2003; Bréda et al. 2006; Genet et al. 2010; El Zein et al. 2011). However, even in the outer rings of the current study, soluble carbohydrate content was fairly high, while starch content was low compared to healthy trees. We observed particularly low starch contents in comparison to Barbaroux et al. (2003) and even more in comparison to Hoch et al. (2003). In the beech trunks examined by Hoch et al. (2003), starch reserves were abundant, while soluble carbohydrate content was similar to that reported in further studies. However, these high levels of starch do not seem to be outliers and were almost the same as those measured at $0.3 \mathrm{~m}$ by Barbaroux et al. (2003). In addition, the beeches studied by Hoch et al. (2003) were in very good health, growing in a highly fertile site, with high growth rates thanks to absence of climatic constraints. The reported carbohydrate content could therefore be regarded as optimal reference values for 
mature, healthy beech trees. TNC distribution in trunk of the studied declining beech trees showed a stronger radial decrease than healthy ones, especially for starch content which abruptly decreased. From these observations, it appears possible that the current long-term decline may be accompanied by a depletion of the carbohydrate reserves in the older wood rings of the trunk, while they were maintained in the outermost wood rings.

Ray parenchyma cells serve as prominent sites of starch storage in beech wood (Essiamah and Eschrich 1985) and the most efficient radial translocation routes (Sauter and Witt 1997). In beech trunks, ray parenchyma is multiseriate and large (up to 20 cells) and accounts for $20 \%$ of total woody tissue (Burgert and Eckstein 2001), and TNC can be detected in the oldest wood rings close to the pith (Magel et al. 1997; Hoch et al. 2003). In the current study, the high proportion of soluble carbohydrates, with very small amounts of starch, may indicate high hydrolysis and mobilization of starch reserves, especially in older rings. Fructose and glucose are intermediates in starch-sucrose conversion, and sucrose is considered to be the main transport carbohydrate in the ray parenchyma (Sauter and Witt 1997). Contrary to the assumption that most starch stored in old rings is sequestered and unusable (Millard et al. 2007), beech would be able to use its deep carbon that could help to sustain the carbon balance in case of multi-year carbon limitation. This hypothesis was discussed in coniferous or tropical species, but up to now never mentioned in beech. Thereby, Vargas et al. (2009) demonstrated that some tropical tree species allocate older carbon pools to growth recovery after extreme conditions causing severe damage to crowns and roots. Similarly, carbohydrates in spruce heartwood can be recycled to support growth of outer tree rings (Höll 1997), and Galiano et al. (2011) observed almost complete depletion of TNC stored in the bole sapwood of Scots pine after several years of extreme drought. Horizontal transfers through the parenchyma rays, from the oldest rings, provide connections with the sieve elements in the phloem, allowing steady carbohydrate contents to be maintained in the most recent rings when replenishment from phloem carbohydrate is limited.

\section{Conclusions}

After cumulated climatic events, the studied beech trees exhibited severe crown conditions. Despite the limited literature available on the TNC of beech, its radial distribution in the trunk seemed to be affected by decline. Starch depletion was more pronounced in the older rings, while carbohydrate contents appear partly maintained in the outermost rings. During long term, under adverse growing conditions, carbohydrate reserves depletion could take place probably together with a gradual increase of C limitation. Finally, whatever the health status, it should be recommended to assess TNC contents in beech trees over the whole radial cross sections. Further investigations are needed on mature beech trees to understand the impact of adverse events on their carbon allocation scheme.

Acknowledgments We gratefully thank François Gérémia and Roger Schipfer for their technical assistance in tree coring and Anthony Poittevin and Cyndie Clément for their help in sample grinding and preparation. Warm thanks are due to Hubert Schmuck from the National Forest Office, who was in charge of the sampling design and assessment of crown condition, within the framework of Forest Health Department (DSF) activities. Jacqueline Marchand is gratefully acknowledged for the HPLC measurements that were performed at the Technical Platform of Functional Ecology (OC 081) at INRA's Unit of Forest Ecology and Ecophysiology.

Funding The research was funded by the National Research Agency (DRYADE project, ANR-06-VULN-004) and the Forest Health Department (DSF) under the Direction Générale de l'Alimentation (DGAAL project 2009-215).

\section{References}

Badeau V, Dupouey JL, Cluzeau C, Drapier J, Le Bas C (2010) Climate change and the biogeography of French tree species: first results and perspectives. In: Loustau D (ed) Forests, carbon cycle and climate change. Quae edn, Paris, pp 231-252

Barbaroux C, Bréda N (2002) Contrasting distribution and seasonal dynamics of carbohydrate reserves in stem wood of adult ringporous sessile oak and diffuse-porous beech trees. Tree Physiol 21:1201-1210. doi:10.1093/treephys/22.17.1201

Barbaroux C, Bréda N, Dufrêne E (2003) Distribution of above-ground and below-ground carbohydrate reserves in adult trees of two contrasting broad-leaved species (Quercus petraea and Fagus sylvatica). New Phytol 157:605-615. doi:10.1046/j.14698137.2003.00681.x

Bréda N, Huc R, Granier A, Dreyer E (2006) Temperate forest trees and stands under severe drought: a review of ecophysiological responses, adaptation processes and long-term consequences. Ann For Sci 63:625-644. doi:10.1051/forest:2006042

Burgert I, Eckstein D (2001) The tensile strength of isolated wood rays of beech (Fagus sylvatica L.) and its significance for the biomechanics of living trees. Trees 15:168-170. doi:10.1007/s004680000086

Desprez-Loustau M-L, Marçais B, Nageleisen L-M, Piou D, Vannini A (2006) Interactive effects of drought and pathogens in forest trees. Ann For Sci 63:597-612. doi:10.1051/forest:2006040

Dittmar C, Elling W (2007) Dendroecological investigation of the vitality of Common Beech (Fagus sylvatica L.) in mixed mountain forests of the Northern Alps (South Bavaria). Dendrochronologia 25:37-56. doi:10.1016/j.dendro.2007.01.003

Dobbertin M (2005) Tree growth as indicator of tree vitality and of tree reaction to environmental stress: a review. Eur J For Res 124:319333. doi:10.1007/s10342-005-0085-3

Dreyer E (1994) Compared sensitivity of seedlings from 3 woody species (Quercus robur L, Quercus rubra L and Fagus silvatica L) to water-logging and associated root hypoxia: effects on water relations and photosynthesis. Ann For Sci 51:417-429. doi:10.1051/forest:19940407

Eichhorn J, Icke R, Isenberg A, Paar U, Schönfelder E (2005) Temporal development of crown condition of beech and oak as a response 
variable for integrated evaluations. Eur J For Res 124:335-347. doi:10.1007/s10342-005-0097-Z

El Zein R, Maillard P, Bréda N, Marchand J, Montpied P, Gérant D (2011) Seasonal changes of $C$ and $N$ non-structural compounds in the stem sapwood of adult sessile oak and beech trees. Tree Physiol 31:843-854. doi:10.1093/treephys/tpr074

E Silva D, Rezende Mazzella P, Legay M, Corcket E, Dupouey JL (2012) Does natural regeneration determine the limit of European beech distribution under climatic stress? For Ecol Manag 266:263-272. doi:10.1016/j.foreco.2011.11.031

Essiamah SK, Eschrich W (1985) Changes of starch content in the storage tissues of deciduous trees during winter and spring. IAWA Bull 6:97-106

Galiano L, Martínez-Vilalta J, Lloret F (2011) Carbon reserves and canopy defoliation determine the recovery of Scots pine 4 year after a drought episode. New Phytol 190:750-759. doi:10.1111/ j.1469-8137.2010.03628.x

Genet H, Bréda N, Dufrêne E (2010) Age-related variation in carbon allocation at tree and stand scales in beech (Fagus sylvatica L.) and sessile oak (Quercus petraea (Matt.) Liebl.) using a chronosequence approach. Tree Physiol 30:177-192. doi:10.1093/ treephys/tpp 105

Gérard B, Alaoui-Sossé B, Badot P-M (2009) Flooding effects on starch partitioning during early growth of two oak species. Trees 23:373-380. doi:10.1007/s00468-008-0286-8

Geßler A, Keitel C, Kreuzwieser J, Matyssek R, Seiler W, Rennenberg H (2007) Potential risks for European beech (Fagus sylvatica L) in a changing climate. Trees 21:1-11. doi:10.1007/s00468-006-0107-x

Granier A, Bréda N, Biron P, Villette S (1999) A lumped water balance model to evaluate duration and intensity of drought constraints in forest stands. Ecol Model 116:269-283. doi:10.1016/S0304-3800 (98)00205-1

Granier A, Bréda N, Longdoz B, Gross P, Ngao J (2008) Ten years of fluxes and stand growth in a young beech forest at Hesse, Northeastern France. Ann For Sci 65:704. doi:10.1051/forest:2008052

Hoch G, Richter A, Körner C (2003) Non-structural carbon compounds in temperate forest trees. Plant Cell Environ 26:1067-1081. doi:10.1046/j.0016-8025.2003.01032.x

Höll W (1997) Storage and mobilization of carbohydrates and lipids. In: Rennenberg H, Eschrich W, Ziegler H (eds) Trees - contributions to modern tree physiology. Backhuys, Leiden, pp 197-211

Innes JL (1998) An assessment of the use of crown structure for the determination of the health of beech (Fagus sylvatica). Forestry 71:113-130. doi:10.1093/forestry/71.2.113

Körner C (2003) Carbon limitation in trees. J Ecol 91:4-17. doi:10.1046/ j.1365-2745.2003.00742.x

Kozlowski TT (1999) Soil compaction and growth of woody plants. Scand J For Res 14:596-619. doi:10.1080/02827589908540825

Leuschner C, Backes K, Hertel D, Schipka F, Schmitt U, Terborg O, Runge M (2001) Drought responses at leaf, stem and fine root levels of competitive Fagus sylvatica L. and Quercus petraea
(Matt.) Liebl. trees in dry and wet years. For Ecol Manag 149:33-46. doi:10.1016/S0378-1127(00)00543-0

Magel EA, Hillinger C, Höll W, Ziegler H (1997) Biochemistry and physiology of heartwood formation: role of reserve substances. In: Rennenberg H, Eschrich W, Ziegler H (eds) Trees-contributions to modern tree physiology. Backhuys, Leiden, pp 477-506

Manion PD (1991) Tree disease concepts, 2nd edn. Prentice Hall, Englewood Cliffs

McDowell NG, Beerling DJ, Breshears DD, Fisher RA, Raffa KF, Stitt $M$ (2011) The interdependence of mechanisms underlying climate-driven vegetation mortality. Trends Ecol Evol 26:523-532. doi:10.1016/j.tree.2011.06.003

Michelot A, Bréda N, Damesin C, Dufrêne E (2012) Differing growth responses to climatic variations and soil water deficits of Fagus sylvatica, Quercus petraea and Pinus sylvestris in a temperate forest. For Ecol Manag 265:161-171. doi:10.1016/ j.foreco.2011.10.024

Millard P, Sommerkorn M, Grelet G-A (2007) Environmental change and carbon limitation in trees: a biochemical, ecophysiological and ecosystem appraisal. New Phytol 175:11-28. doi:10.1111/ j.1469-8137.2007.02079.x

Palacio S, Paterson E, Sim A, Hester AJ, Millard P (2011) Browsing affects intra-ring carbon allocation in species with contrasting wood anatomy. Tree Physiol 31:150-159. doi:10.1093/treephys/ tpq110

Power SA (1994) Temporal trends in twig growth of Fagus sylvatica L. and their relationships with environmental factors. Forestry 67:13-30. doi:10.1093/forestry/67.1.13

R Development Core Team (2010) R: A language and environment for statistical computing. 2.11.0 (2010-04-22) edn. R Foundation for Statistical Computing, Vienna, Austria

Rouault G, Candau J-N, Lieutier F, Nageleisen L-M, Martin J-C, Warzée N (2006) Effects of drought and heat on forest insect populations in relation to the 2003 drought in Western Europe. Ann For Sci 63:613-624. doi:10.1051/forest:2006044

Sala A, Woodruff DR, Meinzer FC (2012) Carbon dynamics in trees: feast or famine? Tree Physiol 32:764-775. doi:10.1093/treephys/ tpr143

Sauter JJ, Witt W (1997) Structure and function of rays: storage, mobilization, transport. In: Rennenberg $\mathrm{H}$, Eschrich W, Ziegler $\mathrm{H}$ (eds) Trees - contributions to modern tree physiology. Backhuys, Leiden, pp 177-195

van der Werf GW, Sass-Klaassen UGW, Mohren GMJ (2007) The impact of the 2003 summer drought on the intra-annual growth pattern of beech (Fagus sylvatica L.) and oak (Quercus robur L.) on a dry site in the Netherlands. Dendrochronologia 25:103-112. doi:10.1016/j.dendro.2007.03.004

Vargas R, Trumbore SE, Allen MF (2009) Evidence of old carbon used to grow new fine roots in a tropical forest. New Phytol 182:710 718. doi:10.1111/j.1469-8137.2009.02789.x 